\title{
SELECTED RECENT ACQUISITIONS
}

\section{Hardin Library for the Health Sciences}

AIDS. Donation of $\$ 1,800$ to the Hardin Library for the purchase of materials on the acquired immunodeficiency syndrome. This grant makes materials available statewide to healthcare professionals. Gift of the College of Medicine, University of Iowa.

Ars Moriendi. Cologne, 1495. Gift of Dr. John Martin.

Baillie, Matthew. The Morbid Anatomy of Some of the Most Important Parts of the Human Body. London, 1793. Gift of Dr. John Martin.

Bernard, Claude. Lecons de Physiologie Operatoire. Paris, 1879. Gift of Dr. John Martin.

Browne, Sir Thomas. A True and Full Copy of That Which Was Most Imperfectly and Surreptitiously Printed Before Under the Name of Religio Medici. London, 1643. Gift of Dr. John Martin.

Fothergill, John. An Account of the Sore Throat Attended with Ulcers. London, 1748. Gift of Dr. John Martin.

Gesner, Konrad. Historia Plantarum et Vires ex Dioscoride, Paulo Aegineta, Theophrasto, Plinio, \& Recentioribus Graecis, Juxta Elementorum Ordinem. Paris, 1541. Gift of Dr. John Martin.

Harvey, William. De Motu Cordis. Frankfurt, 1628. Gift of Dr. John Martin.

Hippocrates. Tou Megalou Hippokratous Panton ton Iatron Koryphaiou ta Heuriskomena [Greek title transliterated]. Opera Omnia quae Extant. Frankfurt, 1595. Gift of Dr. John Martin.

International health materials. A grant of $\$ 2,700$ to the Hardin Library for the purchase of materials on such subjects as tropical medicine. Gift of the Center for International and Comparative Studies, University of Iowa.

Ketham, Johannes de. Wundartznei und der Chirurgen Handtwirckung. Frankfurt, 1534. Gift of Dr. John Martin.

Le Cat, Claude Nicolas. Traite des Sens. Nouvelle edition. Amsterdam, 1744. Gift of Dr. John Martin.

Maitre-Jan, Antoine. Traite des Maladies de L'oeil. Troyes, 1707. Gift of Dr. John Martin.

Mattioli, Pietro Andrea. Opusculum de Simplicium Medicamentorum. Venice, 1569. Gift of Dr. John Martin.

Mechnikov, Il'ia Il'ich. Lecons sur la Pathologie Comparee de L'inflammation. Paris, 1892. Autographed by Sir Humphrey Davey Rolleston. Gift of Dr. John Martin.

Polcastro, Sigismondo. De Restauratione Humidi. Venice, 1490. Gift of Dr. John Martin. 
Pringle, John. Observations on Diseases of the Army. London, 1752. Gift of Dr. John Martin.

Shattuck, George Cheyne. Three Dissertations on Boylston Prize Questions for the Years 1806 and 1807. Boston, 1808. Gift of Dr. John Martin.

Sloane, Hans. An Account of a Most Efficacious Medicine for Soreness, Weakness, and Several Other Distempers of the Eyes. London, 1745. Gift of Dr. John Martin.

Topinard, Paul. L'anthropologie. Paris, 1876. Gift of Dr. John Martin.

Weyer, Johann. Opera Omnia. Amsterdam, 1660. Gift of Dr. John Martin.

\section{Main Library}

Banse, Timothy P. Double Agent: A Cipherbase Program for Defending Your Right to Privacy (1984); The Epson Guide to Personal Computer Communications (1986); Home Applications and Games for the Atari Home Computers (1983); Home Applications and Games for the Commodore 64 (1985); Home Applications and Games for the IBM PC and PCjr (1985); Home Applications and Games for the VIC-20 (1984); and What To Do When Leaded Fuel Becomes Extinct (1986); and as "Eric Helm," Red Dust (1988). Gift of Iowa author Timothy P. Banse.

Cade, Aaron Friend. The Father and Savior of Our Country: the War, Sentiments of Soldiers, and Miscellaneous Subjects, in Prose and Poetry. Burlington, Iowa, 1866. Gift of Mike Maddigan.

Chitty, Joseph. A Practical Treatise on Medical Jurisprudence. Philadelphia: Carey, Lea \& Blanchard, 1835. First American edition. Gift of Alan F. January.

Culinary history. More than 3000 volumes, including international cookery, Hungarian cookery, American cookery, and categories ranging from "aphrodisiacs" through "yogurt." Gift of Chef Louis Szathmary.

Fiction, poetry, and travel. Arkell, Reginald. Green Fingers. New York, 1936; Barrie, J.M. A Window in Thrums. Philadelphia, 1893; Knanishu, Joseph. About Persia and its People. Rock Island, 1899; Moore, Thomas. The Poetical Works. Philadelphia, 1845; Phelps, Eleanor Gaylord. As a Falling Star. Chicago, 1901; Southworth, Mrs. E.D.E.N. Self-Raised. New York, 1884; Warman, Cy. Weiga of Temagami. New York, 1908; Wing, Frank. The Fambly Album. Chicago, 1917. Gift of Harriet Stevens.

Francis, Dorothy Brenner. Thirty-two books, including foreign translations, by the Iowa author of romance novels and children's books. Gift of Dorothy Francis. 
Katz-Levine, Judy. The Umpire and Other Masks. San Francisco: Five Trees Press, 1976. Printed in an edition of 400 copies. Gift of Norman Sage in memory of William Lee Burton.

Keyes, Margaret N. Papers on historic preservation and The University of Iowa Department of Home Economics. Gift of Professor Keyes.

Macagno, Enzo. Seven monographs on Leonardian fluid mechanics. Gift of Professor Macagno.

Maps, prints, and related graphic materials. A gathering of sixty-one items. Gift of Homer Calkin.

Morrell, David. Fifteen volumes, comprising translations in European and Oriental languages for five novels: Brotherhood of the Rose, Fraternity of the Stone, League of Night and Fog, Rambo III, and Testament. Gift of David Morrell.

North Central Publishing Company, St. Paul, Minnesota. Twelve Christmas books published between 1969 and 1980. Gift of Norman Sage.

Paz, Octavio. Three Poems (1987). Gift of Dr. John Martin.

Pownall, Fred M. History of University of Iowa Publications, 1847-1955. Gift of Department of Publications, University of Iowa.

Randle, Kevin D. Once Upon a Murder (1987); Remember the Alamo! (1980); Seeds of War (1986); and his series of Vietnam war novels written as "Eric Helm," including Chopper Command (1985); Guidelines (1987); Incident at Plei Soi (1988); The Raid (1988); Soldier's Medal (1987); and Vietnam - Ground Zero (1986). Gift of Iowa author Kevin D. Randle.

Suckow, Ruth. Three boxes of correspondence, notebooks, and manuscripts of Iowa author Ruth Suckow and her husband Ferner Nuhn. Gift of the Estate of Ferner R. Nuhn.

Updike, John. A collection, comprising 42 items, including his first book, The Carpentered Hen and Other Tame Creatures (1958), the "Bech" and "Rabbit" series, many in signed limited editions. Gift of Charlotte M. Smith.

Venedey, Jacob. Excursions in Normandy, Illustrative of the Character, Manners, Customs, and Traditions of the People . . . (1841). Presented in memory of Maude E. Hitchcock by Mary Gail and Dale Bentz.

Welty, Eudora. A collection, comprising 29 items, including A Curtain of Green (1941); The Golden Apples (1949); The Ponder Heart (1954); The Bride of Innisfallen (1955); Acrobats in a Park (1980); The Collected Stories of Eudora Welty (1980); and One Writer's Beginnings (1984). Gift of Charlotte M. Smith. 